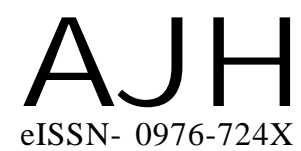

Article history :

Received : 07.10.2016

Revised : 12.11 .2016

Accepted : 22.11.2016
RESEARCH PAPER

THEASIAN JOURNALOF HORTICULTURE

Volume 11 | Issue 2 | December, 2016 | 379-38

Visit us -www.researchjournal.co.in
Members of the Research Forum

Associated Authors:

${ }^{1}$ Agronomy Section, College of

Agriculture, PUNE (M.S.) INDIA

Author for correspondence : A.G. JADHAV

Agronomy Division, College of Agriculture, PUNE (M.S.) INDIA Email : agjadhav95@gmail.com

\section{Growth and fruit yield of coloured capsicum hybrids (Capsicum annum L.) influenced by plant spacing under polyhouse condition}

\section{A.G. JADHAV AND S.L. JANGALE ${ }^{1}$}

ABSTRACT : The plant height, number of branches/plant, leaf area/plant, and fruit yield quintal/hectare was highest in case of capsicum hybrid Orbelle. Whereas, the parameters viz., plant height, number of branches/plant, leaf area/plant, dry matter/plant was more in case of plant spacing $60 \mathrm{~cm}$ x $60 \mathrm{~cm}$. However, the fruit yield (q/ ha) was highest in case of plant spacing $45 \mathrm{~cm} \times 45 \mathrm{~cm}$. The interaction between capsicum hybrid and spacing was found to be non significant.

KEY WORDS : Orbelle, Bomby, Hybrid, Capsicum, Spacing

HOW TO CITE THIS ARTICLE : Jadhav, A.G. and Jangale, S.L. (2016). Growth and fruit yield of coloured capsicum hybrids (Capsicum annum $\mathrm{L}$.) influenced by plant spacing under polyhouse condition. Asian J. Hort., 11(2) : 379-381, DOI : 10.15740/HAS/TAJH/11.2/379-381. 